\section{JURNAL ABDIMAS

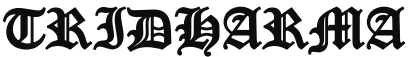 AtA}

P-ISSN 2715-7105, E-ISSN 2716-070X

Jurnal ABDIMAS Vol. 2, No. 1, Januari 2021,Hal (61-66)

@Prodi Manajemen Fakultas Ekonomi Universitas Pamulang

Email: abdimasjurnal.unpam@gmail.com Telp: (021) 741-2566

\title{
BIMBINGAN TEKNIS PEMBUATAN PERATURAN DESA DI DESA KALIMATI, KECAMATAN ADIWERNA, KABUPATEN TEGAL, JAWA TENGAH
}

\author{
Yoyon M Darusman, Susanto, Oksidelfa Yanto, Bastianon, Endi Arofa \\ Universitas Pamulang
}

yoyon.darusman@yahoo.co.id susanto@unpam.ac.id , dosen00240@unpam.ac.id, dosen00987@unpam.ac.id., dosen00987@unpam.ac.id

\begin{abstract}
The Village Regulation is stipulated by the Village Head after being discussed and agreed upon with the Village Consultative Body which is a legal and policy framework in the administration of Village Government and Village Development. The stipulation of Village Regulations is a description of the various powers that the Village has with reference to the provisions of higher laws and regulations. So that as a legal product, the Village Regulation must not conflict with higher regulations and may not harm the public interest. One of the reasons for the promulgation of Law Number 6 of 2014 concerning Villages is the recognition that villages have rights of origin and traditional rights in regulating and managing the interests of the local community and playing a role in realizing the ideals of independence based on the 1945 Constitution of the Republic of Indonesia. This is because the recognition of the village as an autonomous region makes the village have a major role in managing, empowering and advancing the available resources, both natural and human resources. So that in the end they are able to move the wheels of development which must be accompanied by an awareness of the understanding of the spirit of autonomy for all village residents and the capacity of the apparatus as well as the community in understanding governance. Village / Traditional Village Institutions, namely Village / Traditional Village Government institutions consisting of Village / Traditional Village Governments and Village / Traditional Village Consultative Bodies, Village Community Institutions, and traditional institutions. The Village / Traditional Village Head or what is referred to by any other name is the head of the Village / Traditional Village Administration who leads the administration of the Village Government. The Village / Traditional Village Head or what is referred to by any other name has an important role in his position as an extension of the state close to the community and as a community leader. Tri Dharma Perguruan Tinggi is the vision of all tertiary institutions in Indonesia which consists of education and teaching, research and development, and community service. As an effort to realize this vision, the Pamulang University Master of Law study program by involving lecturers and students has held Community Service in the form of providing technical guidance to village heads and the Kalimati Village Consultative Body, Adiwerna District in drafting village regulations to be carried out in Kalimati village, Adiwerna District, Tegal Regency.
\end{abstract}

Keywords: Technical Guidance, Village Regulations

Abstrak
Peraturan Desa ditetapkan oleh Kepala Desa setelah dibahas dan disepakati bersama Badan
Permusyawaratan Desa merupakan kerangka hukum dan kebijakan dalam penyelenggaraan
Pemerintahan Desa dan Pembangunan Desa. Penetapan Peraturan Desa merupakan
penjabaran atas berbagai kewenangan yang dimiliki Desa mengacu pada ketentuan peraturan
perundang-undangan yang lebih tinggi. Sehingga sebagai sebuah produk hukum, Peraturan 
Desa tidak boleh bertentangan dengan peraturan yang lebih tinggi dan tidak boleh merugikan kepentingan umum. Salah satu daru alasan di buatnya Undang-undang Nomor 6 Tahun 2014 tentang Desa adalah pengakuan bahwa Desa memiliki hak asal usul dan hak tradisional dalam mengatur dan mengurus kepentingan masyarakat setempat dan berperan mewujudkan citacita kemerdekaan berdasarkan Undang-Undang Dasar Negara Republik Indonesia Tahun 1945 Hal ini disebabkan karena dengan diakuinya desa sebagai sebuah daerah otonom menjadikan desa memiliki peran utama dalam mengelola, memberdayakan dan memajukan sumber daya yang tersedia, baik sumber daya alam maupun sumber daya manusia. Sehingga pada akhirnya mampu menggerakkan roda pembangunan yang harus diiringi kesadaran akan pemahaman spirit otonomi bagi seluruh penggerak warga desa dan kapasitas perangkat juga masyarakat dalam memahami tata kelola pemerintahan. Kelembagaan Desa/Desa Adat, yaitu lembaga Pemerintahan Desa/Desa Adat yang terdiri atas Pemerintah Desa/Desa Adat dan Badan Permusyawaratan Desa/Desa Adat, Lembaga Kemasyarakatan Desa, dan lembaga adat. Kepala Desa/Desa Adat atau yang disebut dengan nama lain merupakan kepala Pemerintahan Desa/Desa Adat yang memimpin penyelenggaraan Pemerintahan Desa. Kepala Desa/Desa Adat atau yang disebut dengan nama lain mempunyai peran penting dalam kedudukannya sebagai kepanjangan tangan negara yang dekat dengan masyarakat dan sebagai pemimpin masyarakat. Tri Dharma Perguruan Tinggi merupakan visi dari seluruh perguruan tinggi di Indonesia yang terdiri dari pendidikan dan pengajaran, penelitian dan pengembangan, serta pengabdian kepada masyarakat. Sebagai upaya untuk mewujudkan visi tersebut, Program studi Magister Hukum Universitas Pamulang dengan melibatkan Dosen dan para Mahasiswa telah mengadakan Pengabdian Masyarakat dalam bentuk memberikan Bimbingan teknis kepada kepala desa dan Badan Permusyawaratan Desa Kalimati, Kecamatan Adiwerna dalam penyusunan Peraturan desa yang akan dilakukan di desa Kalimati, Kecamatan Adiwerna, Kabupaten Tegal.

\section{Kata Kunci: Bimbingan Teknis, Peraturan Desa}

\section{A. PENDAHUluAN}

Salah satu daru alasan di buatnya Undang-undang Nomor 6 Tahun 2014 tentang Desa adalah pengakuan bahwa Desa memiliki hak asal usul dan hak tradisional dalam mengatur dan mengurus kepentingan masyarakat setempat dan berperan mewujudkan cita-cita kemerdekaan berdasarkan UndangUndang Dasar Negara Republik Indonesia Tahun 1945, Hal ini disebabkan karena dengan diakuinya desa sebagai sebuah daerah otonom menjadikan desa memiliki peran utama dalam mengelola, memberdayakan dan memajukan sumber daya yang tersedia, baik sumber daya alam maupun sumber daya manusia. Sehingga pada akhirnya mampu menggerakkan roda pembangunan yang harus diiringi kesadaran akan pemahaman spirit otonomi bagi seluruh penggerak warga desa dan kapasitas perangkat juga masyarakat dalam memahami tata kelola pemerintahan.

Kelembagaan Desa/Desa Adat, yaitu lembaga Pemerintahan Desa/Desa
Adat yang terdiri atas Pemerintah Desa/Desa Adat dan Badan Permusyawaratan Desa/Desa Adat, Lembaga Kemasyarakatan Desa, dan lembaga adat. Kepala Desa/Desa Adat atau yang disebut dengan nama lain merupakan kepala Pemerintahan Desa/Desa Adat yang memimpin penyelenggaraan Pemerintahan Desa.

Kepala Desa/Desa Adat atau yang disebut dengan nama lain mempunyai peran penting dalam kedudukannya sebagai kepanjangan tangan negara yang dekat dengan masyarakat dan sebagai pemimpin masyarakat. Mengingat kedudukan, kewenangan, dan Keuangan Desa yang semakin kuat, penyelenggaraan Pemerintahan Desa diharapkan lebih akuntabel yang didukung dengan sistem pengawasan dan keseimbangan antara Pemerintah Desa dan lembaga Desa. Lembaga Desa, khususnya Badan Permusyawaratan Desa yang dalam kedudukannya mempunyai fungsi penting dalam menyiapkan kebijakan Pemerintahan Desa bersama Kepala Desa, 


\section{JURNAL ABDIMAS

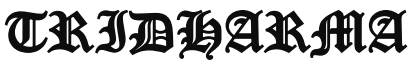 AtA}

P-ISSN 2715-7105, E-ISSN 2716-070X

Jurnal ABDIMAS Vol. 2, No. 1, Januari 2021,Hal (61-66)

@ Prodi Manajemen Fakultas Ekonomi Universitas Pamulang

Email: abdimasjurnal.unpam@ gmail.com Telp: (021) 741-2566 harus mempunyai visi dan misi yang sama dengan Kepala Desa sehingga Badan Permusyawaratan Desa tidak dapat menjatuhkan Kepala Desa yang dipilih secara demokratis oleh masyarakat Desa. Badan Permusyawaratan Desa atau yang disebut dengan nama lain adalah lembaga yang melakukan fungsi pemerintahan yang anggotanya merupakan wakil dari penduduk Desa berdasarkan keterwakilan wilayah dan ditetapkan secara demokratis. Badan Permusyawaratan Desa merupakan badan permusyawaratan di tingkat Desa yang turut membahas dan menyepakati berbagai kebijakan dalam penyelenggaraan Pemerintahan Desa. Dalam upaya meningkatkan kinerja kelembagaan di tingkat Desa, memperkuat kebersamaan, serta meningkatkan partisipasi dan pemberdayaan masyarakat, Pemerintah Desa dan/atau Badan Permusyawaratan Desa memfasilitasi penyelenggaraan Musyawarah Desa.

Berdasarkan permasalahan diatas, maka Tim PKM dari Magister Hukum Universitas Pamulang dengan jumlah 5 dosen bersama 5 mahasiswa mengadakan bimbingan teknis dengan tema "Bimbingan Teknis Pembuatan Peraturan Desa Di Desa Kalimati, Kecamatan Adiwerna, Kabupaten Tegal, Jawa Tengah".

Tujuan dari kegiatan ini adalah memberi pengenalan penyusunan peraturan desa. Kegiatan ini sangat bermanfaat bagi desa khususnya mengenai pembentukan peraturan desa.

\section{B. METODE PELAKSANAAN KEGIATAN}

Pada kegiatan PKM bimbingan teknis penyusunan peraturan desa, dilakukan dengan empat tahap, Tahapan Koordinasi dan Perencanaan, Tahapan Pelaksanaan Kegiatan, Tahapan Monitoring dan Evaluasi dan Tahapan Pelaporan.

Pada tahapan Koordinasi dan Perencanaan, team PKM melakukan peninjauan lokasi dan koordinasi dengan Kepala Desa Kalimati mengenai akan dilaksanakan PKM. Setelah tahapan koordinasi selanjutnya adalah tahapan pelaksanaan, dimana pelaksanaan kegiatan ini dilakukan di Balai Desa Kalimati yang dihadiri oleh Kepala Desa, Aparat Desa, Badan Permusyawaratan Desa, Ketua RT dan RW, Ibu-ibu penggerak PKK dan muda-mudi.

$$
\text { Pelaksanaan PKM ini }
$$
menggunakan metode Bimbingan Teknis dimana peserta diberikan bahan-bahan untuk pembuatan peraturan desa termasuk contoh peraturan desa. Sebelumnya diberikan penjelasan mengenai peraturan desa dan urgensinya dengan pentingnya menyusun peraturan desa yang baik dan benar.

Kegiatan ini dilaksanakan tanggal 27 November 2020 sampai dengan 29 November 2020. Tahapan terakhir adalah melakukan monitoring dan evaluasi pelaksanaan PKM. Dimana diketahui hasil monitoring dan evaluasi terhadap peserta PKM diperoleh data bahwa peserta PKM sudah terbantu dan memahami mengenai pemaparan PKM.

Tahapan terakhir adalah tahapan pembuatan laporan PKM yang kemudian diikuti dengan luaran PKM yaitu pemuatan kegiatan PKM pada jurnal nasional.

\section{HASIL DAN PEMBAHASAN}

Kegiatan Pengabdian Kepada Masyarakat (PKM) yang dilaksanakan pada tanggal 27 November 2020 sampai dengan 29 November 2020 telah berjalan dengan baik dan lancar. Sebelum tanggal tersebut juga dilakukan komunikasi secara intens sebagai analisis awal. Kegiatan ini diikuti Kepala Desa, Aparat Desa, Badan Permusyawaratan Desa, Ketua RT dan RW, Ibu-ibu penggerak PKK dan mudamudi dari Desa Pedeslohor, Kecamatan Adiwerna, Kabupaten Tegal, Jawa Tengah.

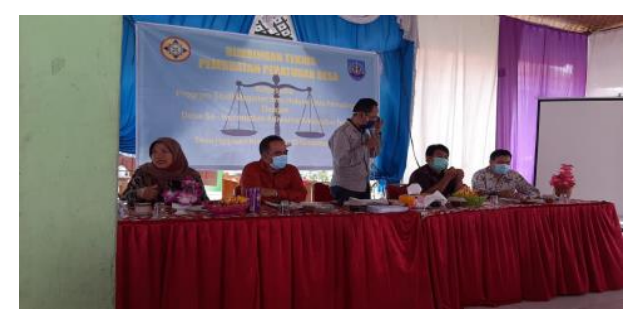

Gambar 1 : Sambutan Camat Adiwerna 


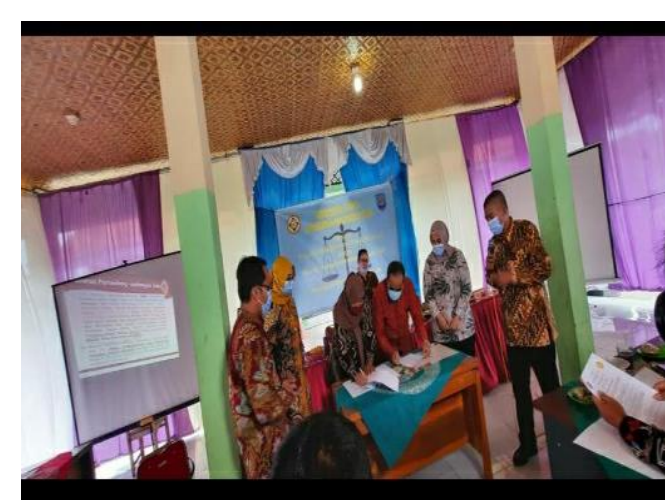

Gambar 2 : Penandatanganan Perjanjian Kerjasama

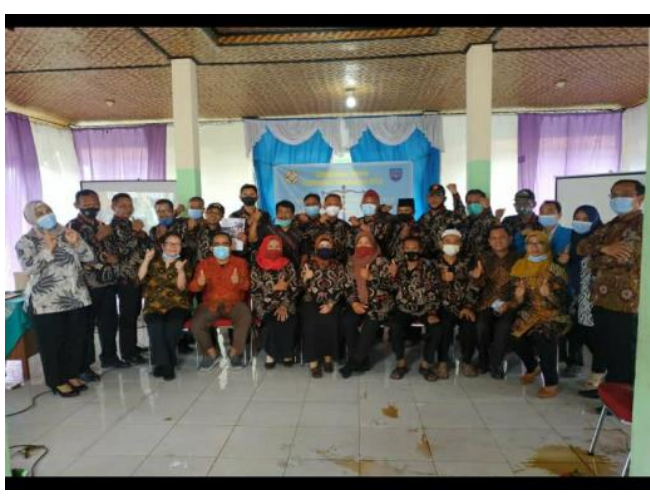

Gambar 3 : Foto Team PKM dan Peserta PKM

Disampaikan oleh pemateri PKM bahwa Kelahiran Undang-Undang Nomor 6 Tahun 2014 tentang Desa membawa perubahan yang signifikan bagi eksistensi desa.Salah satunya adalah kemandirian desa yang lebih kuat, baik dari segi politik, ekonomi, sosial dan budaya.Undangundang desa. Selain itu, desa juga dituntut berperan aktif dalam mewujudkan citacita kemerdekaan sebagaimana tertuang dalam Pembukaan UndangUndang Dasar Negara Republik Indonesia Tahun 1945. Pasal 1 UndangUndang Nomor 6 Tahun 2014 tentang Desa menyatakanbahwa Pemerintahan Desa adalah "penyelenggaraan urusan pemerintahan dan kepentingan masyarakat setempat dalam sistem pemerintahan Negara Kesatuan Republik Indonesia”.

Pasal tersebut menunjukkan bahwa Pemerintah Desa memiliki dua tugas pokok, yaitu sebagai penyelenggara urusan pemerintahan dan penyelenggara kepentingan masyarakat. Siapakah pemerintah desa itu? Dalam Pasal 1 dan
Pasal 25 UndangUndang ini juga dinyatakan bahwa yang dimaksud dengan Pemerintah Desa adalah Kepala Desa atau yang disebut dengan nama lain, dibantu dengan perangkat desa.

Adapun perangkat desa terdiri atas tiga jenis, yaitu: Sekretariat Desa, Pelaksana Kewilayahan, dan Pelaksana Teknis (Pasal 48). Perangkat desa ini diangkat oleh Kepala Desa setelah dikonsultasikan dengan Camat atas nama Bupati/Walikota. Dalam melaksanakan tugas dan wewenangnya, perangkat desa ini bertanggung jawab kepada kepala desa. Dalam menyelenggarakan pemerintahan desa, Kepala Desa memiliki kewenangan yang cukup besar.Pasal 26 UU No. 6 Tahun 2014 menyebutkan 15 kewenangan Kepala Desa.

Kewenangan tersebut yaitu: a) memimpin penyelenggaraan Pemerintahan Desa; b) mengangkat dan memberhentikan perangkat Desa; c) memegang kekuasaan pengelolaan Keuangan dan Aset Desa; d) menetapkan Peraturan Desa; e) menetapkan Anggaran Pendapatan dan Belanja Desa; f) membina kehidupan masyarakat Desa; g) membina ketenteraman dan ketertiban masyarakat Desa; h) membina dan meningkatkan perekonomian Desa serta mengintegrasikannya agar mencapai perekonomian skala produktif untuk sebesar-besarnya kemakmuran masyarakat Desa; i) mengembangkan sumber pendapatan Desa; j) mengusulkan dan menerima pelimpahan sebagian kekayaan negara guna meningkatkan kesejahteraan masyarakat Desa; k) mengembangkan kehidupan sosial budaya masyarakat Desa; 1) memanfaatkan teknologi tepat guna;m) mengoordinasikan Pembangunan Desa secara partisipatif; n) mewakili Desa di dalam dan di luar pengadilan atau menunjuk kuasa hukum untuk mewakilinyasesuai dengan ketentuan peraturan perundangundangan; dan o) melaksanakan wewenang lain yang sesuai dengan ketentuan peraturan perundangundangan.

Selain Kepala Desa dan prangkat desa, organ desa lain yang disebut dalam UU No. 6 Tahun 2014 dan memiliki 


\section{JURNAL ABDIMAS

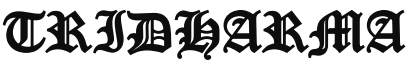

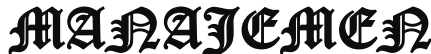

kedudukan penting adalah Badan Permusyawaratan Desa (BPD). Badan ini memiliki tiga macam fungsi: membahas dan menyepakati Rancangan Peraturan Desa bersama Kepala Desa, menampung dan menyalurkan aspirasi masyarakat Desa, dan melakukan pengawasan kinerjaKepala Desa (Pasal 55).

Selain fungsifungsi ini, BPD juga memiliki hak antara lain: a) mengawasi dan meminta keterangan tentang penyelenggaraan Pemerintahan Desa kepada Pemerintah Desa; b) menyatakan pendapat atas penyelenggaraan Pemerintahan Desa, pelaksanaan Pembangunan Desa, pembinaan kemasyarakatan Desa, dan pemberdayaan masyarakat Desa; dan c) mendapatkan biaya operasional pelaksanaan tugas dan fungsinya dari Anggaran Pendapatan dan Belanja Desa (Pasal 61).

Sedangkan para anggotanya berhak mengajukan usul rancangan Peraturan Desa, mengajukan pertanyaan, menyampaikan usul dan/atau pendapat, memilih dan dipilih, dan mendapat tunjangan dari Anggaran Pendapatan dan Belanja Desa. Dari beberapa kewenangan Kepala Desa dan anggota BPD ini, ada satu hal yang penting terkait penyelenggaraan pemerintahan desa, yaitu keberadaan Peraturan Desa (Perdes).

Dalam tata kelola pemerintahan desa, Perdes menjadi sangat krusial karena menjadi dasar hukum bagi pelaksanaan berbagai program dan kegiatan desa. Penjelasan tentang tugas dan wewenang Kepala Desa dan anggota BPD di atas menunjukkan bahwa wewenang penetapan Peraturan Desa ada di Kepala Desa.Tetapi penetapan tersebut hanya bisa dilakukan setelah Rancangan Perdes dibahas dan disepakati bersama BPD (Pasal 69 [3]) Bimbingan teknis Penyusunan Peraturan desa ini akan lidakukan secara langsung/tatap muka dengan seluruh kepala desa dan Badan Permusyawaratan Desa dengan melibatkan Dosen dan Mahasiswa Program Studi Pasca Sarjana Universitas Pamulang, Pelatihan/Bimbingan Teknis (Bimtek) adalah suatu kegiatan dimana para peserta diberi pelatihanpelatihan yang bermanfaat dalam meningkatkan kompetensi peserta yang dimana materi yang diberikan meliputi Membangun Tim Kerja Efektif, Teknik Komunikasi dalam Konteks Pelayanan Prima, Survey Indeks Kepuasan Masyarakat dan Penanganan Keluhan Pelanggan, Tata Pemerintahan yang Baik dan Profesionalisme Aparatur, Kepemimpinan, dll.

Dalam rangka meningkatkan kemampuan Kepala Desa dan Badan Permusyawaratan Desa tersebut dan untuk melaksanakan salah satu Visi Universitas Pamulang khususnya Program studi Magister Hukum akan melaksanakan Pengabdian Masyarakat berupa memberikan Bimbingan teknis dalam penyusunan Peraturan desa. Sebagai sebuah produk hukum, Peraturan Desa tidak boleh bertentangan dengan peraturan yang lebih tinggi dan tidak boleh merugikan kepentingan umum, yaitu: a. terganggunya kerukunan antarwarga masyarakat; b. terganggunya akses terhadap pelayanan publik; c. terganggunya ketenteraman dan ketertiban umum; d. terganggunya kegiatan ekonomi untuk meningkatkan kesejahteraan masyarakat Desa; dan e. diskriminasi terhadap suku, agama dan kepercayaan, ras, antargolongan, serta gender. Sebagai sebuah produk politik,

Peraturan Desa diproses secara demokratis dan partisipatif, yakni proses penyusunannya mengikutsertakan partisipasi masyarakat Desa. Masyarakat Desa mempunyai hak untuk mengusulkan atau memberikan masukan kepada Kepala Desa dan Badan Permusyawaratan Desa dalam proses penyusunan Peraturan Desa. Peraturan Desa yang mengatur kewenangan Desa berdasarkan hak asal usul dan kewenangan berskala lokal Desa pelaksanaannya diawasi oleh masyarakat Desa dan Badan Permusyawaratan Desa.

Hal itu dimaksudkan agar pelaksanaan Peraturan Desa senantiasa dapat diawasi secara berkelanjutan oleh warga masyarakat Desa setempat mengingat Peraturan Desa ditetapkan untuk kepentingan masyarakat Desa. Apabila terjadi pelanggaran terhadap pelaksanaan Peraturan Desa yang telah ditetapkan, 
Badan Permusyawaratan Desa berkewajiban mengingatkan dan menindaklanjuti pelanggaran dimaksud sesuai dengan kewenangan yang dimiliki. Itulah salah satu fungsi pengawasan yang dimiliki oleh Badan Permusyawaratan Desa.

\section{KESIMPULAN DAN SARAN}

\section{Kesimpulan}

Berdasarkan hasil kegiatan PKM pada pada Desa Kalimati, Kecamatan Adiwerna, Kabupaten Tegal, Jawa Tengah dengan metode bimbingan teknis menunjukkan bahwa :

1. Secara umum pada awalnya baik Kepala Desa, BPD, Ketua RT/RW, Ibu-ibu penggerak PHK serta muda mudi desa belum begitu memahami mengenai urgensi Peraturan Desa dan bagaimana pembuatan peraturan desa yang baik dan sesuai dengan ketentuan perundang-undangan.

2. Kepala Desa mengalami beberapa tekanan dari pihak-pihak LSM yang ingin mengetahui berbagai informasi mengenai desa sementara di Desa belum ada payung hokum mengenai teknis atau mekanisme permintaan informasi desa.

\section{Saran}

Berdasarkan hasil pembahasan dan kesimpulan yang diperoleh, maka saran yang diberikan adalah sebagai berikut:

1. Perlu tindak lanjut dan monev mengenai hasil PKM apakah peserta PKM telah mampu menyusun peraturan desa yang baik dan benar.

2. Perlu dilakukan PKM lanjutan terkait dengan implementasi Peraturan Desa yang telah dibuat.

\section{DAFTAR PUSTAKA}

Susanto, M. I. (2019). Kedudukan Hukum People Power Dan Relevansinya Dengan Hak Kebebasan Berpendapat Di Indonesia. Volksgeist: Jurnal Ilmu Hukum Dan Konstitusi, 2(2), 225-237.

Darusman, Y. M., Susanto, S., Anggraeni, R. D., Gueci, R. S., \& Yanto, O.
(2019). Penyuluhan Peraturan Perundang-Undangan Pemilihan Umum (Pemilu) Tahun 2019 (Studi Kasus Pada Politeknik Ilmu Pemasyarakatan (Poltekip) Kementerian Hukum Dan Ham Ri, Depok, Jawa Barat). Jurnal Abdi Masyarakat Humanis, 1(1).

Darusman, Y. M., Susanto, S., Anggraeni, R. D., Bachtiar, B., \& Bastinaon, B. (2020). Sosialisasi Undang-Undang Perlindungan Anak Dan Kdrt Kelurahan Pulau Panggang Kabupaten Kepulauan Seribu. Jurnal Lokabmas Kreatif, 1(1), 76-82.

Darusman, Y. M., Susanto, S., Anggraeni, R. D., Bachtiar, B., \& Bastinaon, B. (2020). Sosialisasi Undang-Undang Perlindungan Anak Dan Kdrt Kelurahan Pulau Panggang Kabupaten Kepulauan Seribu. Jurnal Lokabmas Kreatif, 1(1), 76-82.

Wiyono, B., Arofa, E., Wulansari, E. M., \& Susanto, S. (2020). Sosialisasi Undang-Undang Kdrt Dan Perlindungan Anak. Jurnal Abdimas Tri Dharma Manajemen, 1(3), 42-47

Yanto, O., Susanto, S., Nugroho, A., Santoso, B., \& Gueci, R. S. (2020). Sosialisasi Kekayaan Intelektual Guna Menumbuhkembangkan Usaha Dalam Rangka Menghadapi Persaingan Global Pada Revolusi 4.0. Abdi Laksana, 1(2).

Yanto, O., Susanto, S., Darusman, Y. M., Wiyono, B., \& Gueci, R. S. (2020). Sosialisasi Dan Pelatihan E-Litigasi Di Lembaga Bantuan Hukum Unggul Tangerang Selatan Guna Meningkatkan Profesinalisme Dalam Rangka Pendampingan Masyarakat Pencari Keadilan Melalui Aplikasi Komputer. Jurnal Abdimas Tri Dharma Manajemen, 1(2). 